УДК 378.091.313:005.336.2

DOI: https://doi.org/10.35387/od.2(16).2019.67-75

Іванова Наталя Анатоліївна - здобувач вищої освіти ступеню доктора фрілософрії Мелітопольського державного педагогічного університету імені Богдана Хмельницького

ORCID ID: https://orcid.org/0000-0003-3309-2813

E-mail: ivanova1977@gmail.com

\title{
ПЕДАГОГІЧНІ УМОВИ ФОРМУВАННЯ ПРОЄКТНОЇ КОМПЕТЕНТНОСТІ МАЙБУТНІХ ФАХІВЦІВ 3 ІНФОРМАЦІЙНОЇ, БІБЛІОТЕЧНОЇ ТА АРХІВНОЇ СПРАВИ
}

\begin{abstract}
Анотація. У публікації порушено проблему фрормування практико орієнтованих професійних компетентностей у майбутніх фахівців з інформаційної, бібліотечної та архівної справи, зокрема проєктної компетентності. Важливою характеристикою процесу формування профресійних компетентностей визначено реалізацію певних педагогічних умов. Педагогічні умови фрормування проєктної компетентності визначено як иілеспрямоване проєктування процедур та застосування певної системи з елементів змісту, методів (прийомів), фрорм організації навчання для забезпечення готовності майбутнього фрахівия до здійснення проєктної діяльності в профресійній сфрері. Наголошено на важливості педагогічних умов формування проєктної компетентності, які позитивно впливають на професійний рівень і творчу самореалізацію майбутніх профресіоналів, ефрективність проєктної діяльності як складової профресійноїдіяльності, сприяють їх різнобічному розвитку. Визначено пріоритетні з них: 1) забезпечення мотивації до оволодіння профресією та використання проєктної діяльності як способу професійного зростання; 2) проєктування змісту дисциплін циклу фрахової підготовки; 3) використання інфрормаційно-комунікаційних технологій; 4) оволодіння практичним досвідом здійснення проєктної діяльності; 5) стимулювання рефрлексивної позиції майбутніх фрахівців; 6) формування особистісних $і$ профресійних якостей особистості майбутнього фрахівия. Охарактеризовано їх особливості. Наголошено, що визначені педагогічні умови реалізуються комплексно іє взаємопов'язаними між собою. Доведено, що ефективність формування проєктної компетентності підвищується за умови дотримання поетапного формування ї компонентів в їх взаємозв'язку.
\end{abstract}

Ключові слова: проєктна компетентність, педагогічні умови, майбутні фрахівці з інформаційної, бібліотечної та архівної справи.

Ivanova Natalia - Postgraduate student, Melitopol Bohdan Khmelnytsky State Pedagogical University

ORCID ID: https://orcid.org/0000-0003-3309-2813

E-mail: ivanova1977@gmail.com 


\title{
PEDAGOGICAL CONDITIONS FORMATION OF THE PROJECT COMPETENCE OF FUTURE SPECIALISTS IN INFORMATION, LIBRARY AND ARCHIVE SERVICES
}

\begin{abstract}
The publication deals with the problem of forming modern practically oriented professional competences of future specialists in information, library and archival service, in particular the project competence. In the process of professional competences formation, an important characteristic which can significantly improve their development is the realization of certain pedagogical conditions. The pedagogical conditions of project competence formation are defined as purposeful selection, designing of procedures and application of a certain system of content elements, methods (techniques), forms of training organization to ensure the future specialist's readiness to carry out project activity in the professional sphere. A special place in project competence formation is given to pedagogical conditions that positively influence the professional level and creative self-realization of future specialists, organization of project activity in the process of professional work, improvement of the activities efficiency, contribute to their versatile development. Among them the priority conditions were identified: 1) ensuring positive motivation for mastering the future profession and using project activity as a way of professional growth; 2) development of the content of professional training disciplines; 3) use of information and communication technologies; 4) mastering practical experience of project activity; 5) stimulating the reflective position of future specialists; 6) formation of personal and professional qualities of the future specialist's personality. The characteristics of their features are given. It is emphasized that certain pedagogical conditions are implemented in a complex and interconnected way. It is proved that the effectiveness of project competence formation is enhanced by keeping to the phased formation of its components in their unity and interrelation (value-motivational, knowledgecontent, technological, reflexive-evaluation phases).
\end{abstract}

Key words: the project competence, pedagogical conditions, future specialists in information, library and archive services.

Постановка проблеми, ї актуальність. Сучасний період розвитку суспільства характеризується великим ступенем складності, швидкістю змін у всіх сферах та стрімким зростанням накопичення інформаційних даних, використанням нових інформаційно-комунікаційних технологій, посиленням впливу інформації на всі сфери суспільного життя. Це висуває особливі вимоги до професійної компетентності фахівців тих галузей, які мають фуннкції створення, обробки та розповсюдження інформації. До таких профресій належать і фахівці 3 інфрормаційної, бібліотечної та архівної справи.

Зазначені суспільні зміни ускладнюють не тільки інформаційнобібліотечне обслуговування, а й всю систему бібліотечної діяльності, яка 
все більше має ставати мобільною, різноплановою, включати нові напрями і форми роботи, які мають задовольняти все зростаючі потреби своїх користувачів. Зокрема, сприяння засвоєнню користувачем знання, необхідного йому для застосування на практиці, в рамках надання бібліотечної послуги може забезпечити проєктна діяльність як бібліотеки в цілому, так і окремого фрахівця. Потенціал у використанні в якості бібліотечної послуги проєктної діяльності заслуговує на особливу увагу українських та зарубіжних науковців.

На сьогодні доводиться констатувати, що існує невідповідність наукового обґрунтування змісту і механізмів підвищення ефрективності проєктної діяльності фрахівців інфрормаційної, бібліотечної та архівної справи актуальним вимогам до професійної компетентності цих фрахівців. Особливо загострюється ця проблема у зв'язку з недослідженістю окремих аспектів професійної освіти фрахівців інформаційної, бібліотечної та архівної справи.

Тому особливої актуальності в сучасних умовах набуває питання формування сучасних практико орієнтованих професійних компетентностей, зокрема проєктної, у майбутніх фахівців з інформаційної, бібліотечної та архівної справи в умовах професійної підготовки.

Аналіз останніх досліджень i публікацій. Проблема формування проєктної компетентності, як складника професійної компетентності майбутніх фрахівців інформаційної, бібліотечної та архівної справи достатньо досліджена на рівні концептуальних основ педагогіки, психології та дидактики (В. Беспалько, А. Маркова, В. Сластьонін та ін.). Значний внесок до розуміння суті професійної компетентності внесли праці О. Дубасенюк, І. Зимньої, $\quad$ В. Кременя, Н. Ничкало, О. Пометун, А. Хуторського та ін. Проблеми формування професійної компетентності майбутніх фахівців розкриваються в працях Л. Виготського, В. Долл, М. Елькіна, С. Ізбаш, С. Прийми. Дослідженням сутності та класифрікації педагогічних умов у контексті розкриття тих, що безпосередньо мають вплив на формування конкурентоспроможності фрахівців у різних профресійних напрямках, займалися Р. Гуревич, В. Радкевич, В. Сластьонін та ін.

Таким чином, незважаючи на значні результати зазначених досліджень, $€$ актуальним науковим завданням визначення педагогічних умов фрормування проєктної компетентності майбутніх фрахівців 3 інформаційної, бібліотечної та архівної справи як одного із засобів вирішення суперечностей між потребами сучасної практики до компетентних фрахівців та рівнем їхньої підготовки в закладах освіти.

Метою дослідження $€$ визначення та теоретичне обґрунтування педагогічних умов фрормування проєктної компетентності майбутніх фрахівців з інформаційної, бібліотечної та архівної справи в процесі фрахової підготовки.

Виклад основного матеріалу дослідження. Формування проєктної компетентності майбутніх фахівців з інформаційної, бібліотечної 
та архівної справи розглядається нами як складний інтегрований процес, спрямований на усвідомлення мотивів, потреб в ефективному використанні засобів проєктної діяльності в професійній сфрері, що передбачає оволодіння теоретичними знаннями та розуміння сутності проєктування та управління проєктною діяльністю; практичне оволодіння способами і засобами проєктної діяльності; готовність і здатність застосовувати новий професійний досвід у здійсненні конкретних практичних завдань; усвідомлення фахівцем відповідності рівня своїх професійних можливостей і умінь рівню, необхідному для якісної реалізації проєктної діяльності та ефективної соціальної взаємодії.

Незважаючи на те, що сучасний освітній процес у закладах вищої освіти, де закладаються основи проєктної компетентності майбутніх фахівців 3 інформаційної, бібліотечної та архівної справи, характеризується активним пошуком найефективніших способів інтенсифікації та модернізації системи підвищення якості професійної підготовки, він не вирішує означену проблему. Наявні педагогічні технології не забезпечують повноцінне формування проєктної компетентності майбутніх практиків.

Досліджуючи проблематику формування проєктної компетентності майбутніх фахівців з інформаційної, бібліотечної та архівної справи у процесі професійної підготовки, можна зазначити, що однією з головних характеристик процесу формування професійних компетентностей, що може значно покращити їх становлення, є реалізація певних педагогічних умов. В науковій літературі під педагогічними умовами прийнято розуміти комплекс взаємопов'язаних обставин, що сприяють досягненню запланованих результатів освіти, який застосовують з метою досягнення майбутніми фахівцями необхідного рівня професійної підготовки.

Аналіз визначень за різними науковцями поняття «педагогічні умови» наведемо у таблиці 1.

Таблиця 1

Сутність поняття «педагогічні умови» за різними джерелами

\begin{tabular}{|c|c|}
\hline Назва дефініції & Визначення, автор \\
\hline $\begin{array}{l}\text { педагогічні умови як } \\
\text { відбір критеріїв вибору } \\
\text { оптимальної } \\
\text { навчання }\end{array}$ & $\begin{array}{lccr}\text { педагогічні } & \text { обставини, які } & \text { сприяють } & \text { (або } \\
\text { протидіють) } & \text { проявам } & \text { педагогічних } \\
\text { закономірностей, } & \text { обумовлених } & \text { дією } & \text { певних } \\
\text { факторів (Бабанський, 1989). } & & \end{array}$ \\
\hline педагогічні умови & $\begin{array}{l}\text { обставини, за яких відбувається цілісний } \\
\text { продуктивний педагогічний процес професійної } \\
\text { підготовки фахівців, що опосередковується } \\
\text { активністю особистості, } \\
\text { (Семенова, 2006, с.193). }\end{array}$ \\
\hline педагогічні умови & $\begin{array}{l}\text { складова інноваційної педагогічної діяльності, } \\
\text { спрямована на підготовку висококваліфікованих } \\
\text { фахівців, що забезпечує виконання Державних } \\
\text { стандартів професійної освіти (Моторна, 2008). }\end{array}$ \\
\hline педагогічні умови & структурна оболонка педагогічних моделей і \\
\hline
\end{tabular}




\begin{tabular}{|l|l|}
\hline & $\begin{array}{l}\text { технологій; а дотримання педагогічних умов дає } \\
\text { змогу реалізувати на практиці необхідні } \\
\text { компоненти технології (Гуцан). }\end{array}$ \\
\hline педагогічні умови & закономірні основи, об'єктивні підвалини, \\
покладені в основу технології; причини, від яких \\
залежить якість освіти, що мають бути не лише \\
чіткорормульовані, а й досконало кількісно \\
виміряні та представлені в результатах \\
експериментальних досліджень (Підласий, 2004).
\end{tabular}

Отже, педагогічні умови формування проєктної компетентності майбутніх фрахівців 3 інфрормаційної, бібліотечної та архівної справи визначаємо як цілеспрямований відбір, проєктування процедур та застосування певної системи з елементів змісту, методів (прийомів), форм організації навчання для забезпечення готовності майбутнього фрахівця 3 інформаційної, бібліотечної та архівної справи до здійснення проєктної діяльності в професійній сфрері.

Через узагальнення досліджених аспектів трактування педагогічних умов, нами визначено пріоритетні педагогічні умови, необхідні для фрормування проєктної компетентності майбутніх фрахівців 3 інформаційної, бібліотечної та архівної справи: 1) забезпечення позитивної мотивації до оволодіння майбутньою професією та використання проєктної діяльності як способу професійного зростання; 2) проєктування змісту дисциплін циклу фахової підготовки (збагачення форм, методів, прийомів навчання, адекватних визначеному змісту підготовки); 3) використання інформаційно-комунікаційних технологій; 4) оволодіння практичним досвідом здійснення проєктної діяльності для виконання відповідних обов'язків в майбутній професійній сфрері; 5) стимулювання рефлексивної позиції майбутніх фрахівців на всіх етапах розвитку проєктної компетентності; 6) формування особистісних і професійних якостей особистості майбутнього фрахівця.

Вони становлять єдину систему, що характеризується наявністю компонентів для досягнення готовності майбутнього фахівця до здійснення проєктної діяльності в практиці професійної роботи.

Основні характеристики зазначених педагогічних умов, що виявилися найбільш ефективними при формуванні проєктної компетентності майбутніх фрахівців 3 інформаційної, бібліотечної та архівної справи в результаті проведених досліджень, викладено в таблиці 2. 


\section{Характеристика пріоритетних педагогічних умов при формуванні проєктної компетентності майбутніх фахівців 3 інформаційної, бібліотечної та архівної справи}

\begin{tabular}{|c|c|}
\hline Педагогічна умова & Характеристика \\
\hline $\begin{array}{l}\text { Забезпечення } \\
\text { позитивної мотивації до } \\
\text { оволодіння майбутньою } \\
\text { професією та } \\
\text { використання проєктної } \\
\text { діяльності як способу } \\
\text { професійного зростання }\end{array}$ & $\begin{array}{l}\text { Розвиток інтересу до навчання; формування } \\
\text { ставлення до майбутньої професійної діяльності } \\
\text { як особистісної і соціальної цінності, усвідомлення } \\
\text { значущості формування особистісних якостей і } \\
\text { умінь, формування потреби в професійному } \\
\text { зростанні. Таким чином забезпечується } \\
\text { формування стійкого позитивного інтересу } \\
\text { майбутніх фахівців до професійної діяльності } \\
\text { (Корчагіна, 2014), потреби в проєктній діяльності, } \\
\text { потягу до творчого вирішення професійних } \\
\text { завдань, прагнень постійного професійного } \\
\text { зростання та самовдосконалення. }\end{array}$ \\
\hline $\begin{array}{l}\text { Проєктування змісту } \\
\text { дисциплін фахової } \\
\text { підготовки (створення } \\
\text { якісного навчально- } \\
\text { методичного } \\
\text { забезпечення, } \\
\text { розширення фрорм, } \\
\text { методів, прийомів } \\
\text { навчання, адекватних } \\
\text { визначеному змісту } \\
\text { підготовки до } \\
\text { професійної проєктної } \\
\text { діяльності) }\end{array}$ & 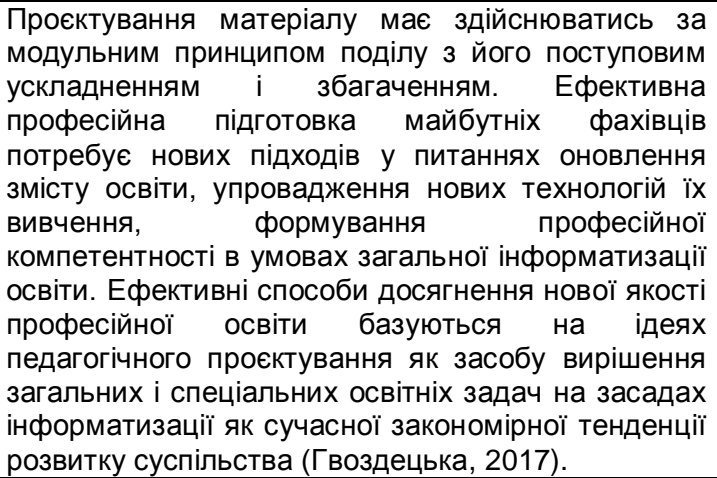 \\
\hline $\begin{array}{l}\text { Використання } \\
\text { інфоромаційно- } \\
\text { комунікаційних } \\
\text { технологій }\end{array}$ & 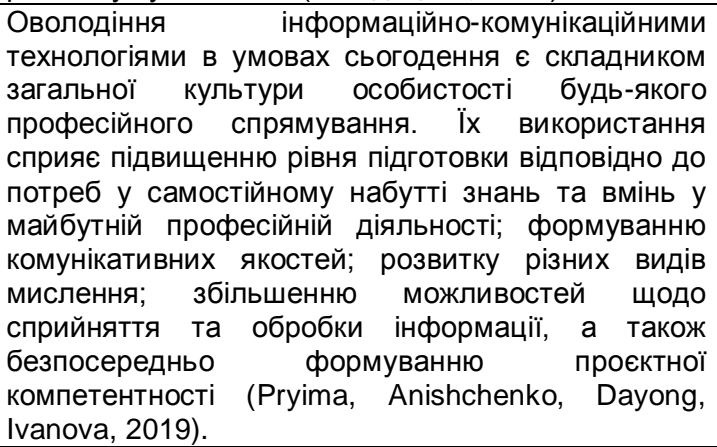 \\
\hline Оволодіння практичним & Ця педагогічна умова важлива 3 огляду \\
\hline
\end{tabular}




\begin{tabular}{|c|c|}
\hline $\begin{array}{l}\text { досвідом здійснення } \\
\text { проєктної діяльності для } \\
\text { виконання відповідних } \\
\text { обов'язків в майбутній } \\
\text { професійній сфері }\end{array}$ & $\begin{array}{l}\text { урахування технологічного компонента проєктної } \\
\text { компетентності майбутніх фахівців } \\
\text { інформаційної, бібліотечної та архівної справи, } \\
\text { оскільки майбутні фахівці мають набути вмінь і } \\
\text { навичок практично реалізовувати принципи, } \\
\text { підходи, застосовувати способи та методи } \\
\text { впровадження проєктів. }\end{array}$ \\
\hline $\begin{array}{l}\text { Стимулювання } \\
\text { рефлексивної позиції } \\
\text { студентів на всіх етапах } \\
\text { розвитку проєктної } \\
\text { компетентності }\end{array}$ & $\begin{array}{l}\text { На важливості } \text { рефлексивності } 9 \text { як } \\
\text { конструювальної характеристики свідомості } \\
\text { наголошено Л. Виготським (Виготський, 1982). У } \\
\text { формуванні проєктної компетентності важливим } \\
\text { аспектом є здатність до рефлексії та оцінки } \\
\text { власної діяльності і діяльності проєктної команди. } \\
\text { Рефлексія допомагає вчитися, розвивати навички, } \\
\text { уникати повторення помилок і постійно } \\
\text { вдосконалюватися. }\end{array}$ \\
\hline $\begin{array}{l}\text { Формування } \\
\text { особистісних та } \\
\text { професійних якостей } \\
\text { особистості майбутнього } \\
\text { фахівця }\end{array}$ & $\begin{array}{l}\text { За умов позитивної мотивації у майбутнього } \\
\text { фахівця фрормується цілісне уявлення про } \\
\text { особливості професійної діяльності, яке } \\
\text { уможливлює формування, розвиток і ефективну } \\
\text { реалізацію особистісних характеристик, що є } \\
\text { визначальними у переліку професійно значущих } \\
\text { якостей особистості. }\end{array}$ \\
\hline
\end{tabular}

Так само, як і всі компоненти проєктної компетентності майбутніх фахівців з інформаційної, бібліотечної та архівної справи складають цілісну структуру, так і визначені педагогічні умови реалізуються комплексно, $є$ взаємопов'язаними між собою та базуються на використанні компетентнісного підходу у підготовці фахівців в процесі професійної підготовки. Ефективність формування проєктної компетентності підвищується за умови дотримання поетапного формування її компонентів в їх єдності та взаємозв'язку (ціннісно-мотиваційний, знаннєво-змістовий, технологічний, рефлексивно-оцінювальний етапи).

Висновки та перспективи подальших досліджень. Розглядаючи педагогічні умови в контексті формування проєктної компетентності майбутніх фахівців з інформаційної, бібліотечної та архівної справи у процесі професійної підготовки ми дійшли висновку, що дослідження процесу формування професійних компетентностей $\epsilon$ складним і багатовимірним процесом, що вимагає розробку моделі, обґрунтування вибору інструментарію дослідження, створення чіткої методики та тлумачення отриманих експериментальних даних, а також реалізації педагогічних умов, як такого освітнього середовища, що $\epsilon$ сприятливим для здійснення цього процесу.

Вважаємо, що реалізація окреслених пріоритетних педагогічних умов забезпечить організацію освітнього процесу таким чином, що забезпечить становлення особистості студента як фахівця з інформаційної, 
бібліотечної та архівної справи, який володіє проєктною компетентністю на відповідному до вимог сучасного інформаційного суспільства рівні.

Перспективу подальших досліджень убачаємо в розробленні спеціального науково-обґрунтованого інструментарію - фракторнокритеріальної моделі формування проєктної компетентності майбутніх фахівців з інформаційної, бібліотечної та архівної справи у процесі професійної підготовки; в розробленні та впровадженні цілісної технології формування в майбутніх фахівців з інформаційної, бібліотечної та архівної справи проєктної компетентності; розробці спеціальних курсів, що сприяли б узагальненому формуванню проєктної компетентності майбутніх фрахівців з інформаційної, бібліотечної та архівної справи.

\section{Список використаних джерел}

Бабанский, Ю. К. (1989). Интенсифрикация процесса обучения. Избранные педагогические труды: Сост. М. Ю. Бабанский. М.: Педагогика. 560.

Выготский, Л. С. (1982). Динамика и структура личности подростка. Хрестоматия по возрастной и педагогической психологии. М.: Педагогика. 138-142.

Гвоздецька, Ю. В. (2017) Педагогічні умови фрормування професійної компетентності майбутніх викладачів з основ технологій харчових виробництв у процесі фахової підготовки. Збірник наукових праць [Херсонського державного університету]. Педагогічні науки. 78(3). C. 104-108. URL: http://nbuv.gov.ua/UJRN/znppn_2017_78(3)_21.

Гуцан, Т. Г. Педагогічні умови формування готовності майбутніх вчителів економіки до профрільного навчання старшокласників. Соціум. Наука. Культура. URL: http://intkonf.org/gutsan-tg-pedagogichniumovi-formuvannya-gotovnosti-maybutnihvchiteliv-ekonomiki-doprofilnogo-navchannya-starshoklasnikiv.

Корчагіна, Г. С. (2014). Розвиток пізнавального інтересу майбутніх учителів музичного мистецтва в процесі фахової підготовки. Оновлення змісту, фрорм та методів навчання $і$ виховання в закладах освіти. 9. 31-34.

Литвин, А., Мацейко, О. (2013). Методологічні засади поняття «педагогічні умови». Педагогіка і психологія профессійної освіти. 4. 43-63. URL: http://nbuv.gov.ua/UJRN/Pippo_2013_4_5.

Моторна, Л. В. (2008). Педагогічні умови застосування освітніх технологій в процесі викладання природничо-наукових дисциплін у технічних колледжах. Гуманізм та освіта: IX міжнародна науковопрактична конфреренція. 10-12 червня 2008 p. URL: http://conf.vntu.edu.ua/humed/2008/txt/Motorna.php.

Підласий, І. П. (2004). Практична педагогіка або три технології : інтерактивний підручник для педагогів ринкової системи освіти. Київ : Видавничий дім «Слово». 616. 
Словник-довідник з професійної педагогіки (2006). Ред. А. В. Семенова. Одеса : Пальміра, 364.

Pryima, S., Anishchenko, O., Dayong, Yuan, Ivanova N. (2019). Formation of the project competence of future specialists in information, library and archive services under the conditions of society digitalization. Information Technologies and Learning Tools. 64. 2.

\section{References (translated and transliterated)}

Babanskij, Ju. (1989). K. Intensification of learning process. Izbrannye pedagogicheskie trudy: Sost. M. Ju. Babanskij. M. : Pedagogika. 560 p. (in Russian).

Vygotskij, L. S. (1982). Dynamics and structure of a teenager's personality. Hrestomatija po vozrastnoj i pedagogicheskoj psihologii. M. : Pedagogika. 138-142. (in Russian).

Hvozdec'ka, Ju. V. (2017). Pedagogical conditions for the formation of future teachers' professional competence in the basics of food production technologies in the process of professional training. Zbirnyk naukovyx prac' [Xersons'koho deržavnoho universytetu]. Pedahohični nauky. 78(3). 104108. URL: http://nbuv.gov.ua/UJRN/znppn_2017_78(3)_21. (in Ukrainian).

Hucan, T. H. Pedagogical conditions for the formation of readiness of future economics teachers to subject-oriented education of high school students. Socium. Nauka. Kul'tura. URL: http://intkonf.org/gutsan-tg-pedagogichniumovi-formuvannya-gotovnosti-maybutnihvchiteliv-ekonomiki-doprofilnogo-navchannya-starshoklasnikiv. (in Ukrainian).

Korčahina, H. S. (2014). Development of cognitive interest of future music teachers in the process of professional training. Onovlennja zmistu, form ta metodiv navčannja i vyxovannja v zakladax osvity. 9. 31-34. (in Ukrainian).

Lytvyn, A., Macejko, O. (2013). Methodological grounds of the notion «pedagogical conditions». Pedahohika i psyxolohija profesijnoji osvity. 4. 43-63. URL: http://nbuv.gov.ua/UJRN/Pippo_2013_4_5. (in Ukrainian).

Motorna, L. V. (2008). Pedagogical conditions of using educational technologies in the process of teaching natural sciences in polytechnic colleges. Humanizm ta osvita: IX mižnarodna naukovo-praktyčna konferencija. 10-12 červnja 2008 r. URL: http://conf.vntu.edu.ua/humed/2008/txt/Motorna.php. (in Ukrainian).

Pidlasyj, I. P. (2004). Practical pedagogy or three technologies: interactive textbook for teachers in market education system. Kyjiv : Vydavnyčyj dim «Slovo». 616 p. (in Ukrainian).

Reference book on professional pedagogy (2006). Red. A. V. Semenova. Odesa : Pal'mira. 364 p. (in Ukrainian).

Pryima, S., Anishchenko, O., Dayong, Yuan, Ivanova, N. (2019). Formation of the project competence of future specialists in information, library and archive services under the conditions of society digitalization. Information Technologies and Learning Tools. 64. 2. 